\title{
First Detection of SARS-CoV-2 B.1.1.7 Variant of Concern in an Asymptomatic Dog in Spain
}

\author{
Sandra Barroso-Arévalo ${ }^{1,2, * \mathbb{D}}$, Belén Rivera ${ }^{1,2}$, Lucas Domínguez ${ }^{1,2}$ and José M. Sánchez-Vizcaíno ${ }^{1,2}$ \\ 1 VISAVET Health Surveillance Center, Animal Health Department, Complutense University of Madrid, \\ 28040 Madrid, Spain; belenriv@ucm.es (B.R.); lucasdo@visavet.ucm.es (L.D.); jmvizcaino@ucm.es (J.M.S.-V.) \\ 2 Department of Animal Health, Faculty of Veterinary, Complutense University of Madrid, 28040 Madrid, Spain \\ * Correspondence: sandrabarroso@ucm.es
}

check for updates

Citation: Barroso-Arévalo, S.; Rivera, B.; Domínguez, L.; Sánchez-Vizcaíno, J.M. First Detection of SARS-CoV-2 B.1.1.7 Variant of Concern in an Asymptomatic Dog in Spain. Viruses 2021, 13, 1379. https://doi.org/ $10.3390 / v 13071379$

Academic Editors: Luis

Martinez-Sobrido and Fernando

Almazan Toral

Received: 11 June 2021

Accepted: 12 July 2021

Published: 15 July 2021

Publisher's Note: MDPI stays neutral with regard to jurisdictional claims in published maps and institutional affiliations.

Copyright: (c) 2021 by the authors. Licensee MDPI, Basel, Switzerland. This article is an open access article distributed under the terms and conditions of the Creative Commons Attribution (CC BY) license (https:// creativecommons.org/licenses/by/ $4.0 /)$.

\begin{abstract}
Natural SARS-CoV-2 infection in pets has been widely documented during the last year. Although the majority of reports suggested that dogs' susceptibility to the infection is low, little is known about viral pathogenicity and transmissibility in the case of variants of concern, such as B.1.1.7 in this species. Here, as part of a large-scale study on SARS-CoV-2 prevalence in pets in Spain, we have detected the B.1.1.7 variant of concern (VOC) in a dog whose owners were infected with SARS-CoV-2. The animal did not present any symptoms, but viral loads were high in the nasal and rectal swabs. In addition, viral isolation was possible from both swabs, demonstrating that the dog was shedding infectious virus. Seroconversion occurred 23 days after the first sampling. This study documents the first detection of B.1.1.7 VOC in a dog in Spain and emphasizes the importance of performing active surveillance and genomic investigation on infected animals.
\end{abstract}

Keywords: SARS-CoV-2; variant of concern; dog; B.1.1.7; pet; reverse zoonosis

\section{Introduction}

Since December 2019, the severe acute respiratory syndrome coronavirus-2 (SARSCoV-2) has spread worldwide, triggering one of the most challenging pandemics so far [1,2]. In the last months, several variants of this virus have been reported [3,4], some of which have raised additional concern due to increased transmissibility [5], higher rates of mortality [6], escape from immune system response [7], altered vaccine effectiveness [7,8] or failure in diagnosis tests [9]. These variants of concern (VOC) carry several genetic mutations, most of which are at the level of the spike (S) protein receptor-binding domain (RBD), which plays a key role in triggering virus entry into the cell, by binding to the cell host angiotensin-converting enzyme 2 (ACE-2) receptor. To date, four VOC have been described, including B.1.1.7 (also referred to as 20I/N501Y.V1), first detected in the United Kingdom (UK) [3]; B.1.351 (20J/N501Y.V2), first identified in South Africa [4]; P.1 (20I/N501Y.V3), detected in Brazil; and B.1.617 (G/452R.V3), recently identified in India. The origin of these variants remains unclear. Taking into account the susceptibility of several animal species to the virus [10] and the mechanisms underlying mutations [11], a zoonotic source cannot be dismissed. Indeed, a recent study based on an extensive phylogenetic assay has reported that Mustelidae, Felidae and especially Canidae families could be a possible host of the direct progenitor of variant B.1.1.7 [12]. Additionally, human-to-animal transmission of SARS-CoV-2 has been widely demonstrated under natural conditions [13-16], which may increase the mutation rate of the virus, due to viral adaptation to the host [17]. However, little is known about the potential pathogenicity and transmission rates of these variants in animal hosts. Therefore, surveillance of SARS-CoV-2 in animals and genetic investigation of viruses that have been isolated from infected pets is critical for understanding the transmission and evolution of the virus. Here, we document the detection of the B.1.1.7 VOC in a dog living with its infected owners, as part of a large-scale study of SARS-CoV-2 prevalence in pets in Spain. This is, to our knowledge, the first detection of this variant 
in a dog in Spain, which is a country with a high rate of SARS-CoV-2 infection. This outcome evidences that B.1.1.7 variant transmission from humans to animals can occur, and emphasizes the importance of studying the VOC spread from humans to animals.

\section{Materials and Methods}

2.1. Detection of SARS-CoV-2 Infection by Reverse Transcription-Quantitative PCR (RT-qPCR) and Virus Isolation

Nasal and rectal swabs were collected in DeltaSwab ${ }^{\circledR}$ Virus $3 \mathrm{~mL}$ contained in viral transport media (VTM) (Deltalab S.L., Cataluña, Spain) using protocols approved by the Complutense University of Madrid's ethics committee for animal experiments (project license 14/2020). RNA from these swabs was extracted using the KingFisher Flex System automated extraction instrument (Thermo Fisher, Waltham, MA, USA), with the MagMAX $\mathrm{viral} /$ pathogen nucleic acid isolation kit (Thermo Fisher), according to the manufacturer's instructions. The detection of SARS-CoV-2 RNA was performed using the envelope protein (E)-encoding gene (Sarbeco) and two targets (IP2 and IP4) of the RNA-dependent RNA polymerase gene (RdRp) in an RT-qPCR protocol established by the World Health Organization, according to the guidelines that can be found at https:/ / www.who.int/emergencies/ diseases/novel-coronavirus-2019/technical-guidance/laboratory-guidance (accessed on 1 July 2020) [18].

Viral isolation was performed using the previously described methods in [16]. Briefly, specimens that tested positive for qRT-PCR were subjected to virus isolation in Vero E6 cells (ATCC $^{\circledR}$, Manassas, VA, USA). These cells were cultured in Gibco Roswell Park Memorial Institute (RPMI) 1640 medium with L-glutamine (Lonza Group Ltd., Basel, Switzerland) and supplemented with $100 \mathrm{IU} / \mathrm{mL}$ penicillin, $100 \mu \mathrm{g} / \mathrm{mL}$ streptomycin, and $10 \%$ fetal bovine serum (FBS) (Merck KGaA, Darmstadt, Germany) (growth medium). The cells were then seeded in 96-well culture plates and cultured at $37^{\circ} \mathrm{C}$ with $5 \% \mathrm{CO}_{2}$ for 24 to $48 \mathrm{~h}$, after which they were inoculated with $10 \mu \mathrm{L}$ of the direct sample contained in VTM (oronasal or rectal swabs). Mock-inoculated cells were used as negative controls. The cultured cells were maintained at $37^{\circ} \mathrm{C}$ with $5 \% \mathrm{CO}_{2}$, with a daily observation of $\mathrm{CPE}$ and cellular death After 6 days, the cell cultures were frozen, thawed, and subjected to three passages with inoculations of fresh Vero E6 cell cultures with the lysates, as described above. SARS-CoV-2 molecular detection was performed by employing RT-qPCR on the supernatants from every passage in order to confirm the presence/absence of the virus in the cell culture and virus recovery by means of the decrease in $\mathrm{Ct}$.

\subsection{Neutralizing Antibody Detection by Virus Neutralization Test (VNT)}

Sera were tested for neutralizing antibodies against SARS-CoV-2 employing a virus neutralization test (VNT). Briefly, the VNT was performed in duplicate in 96-well plates by incubating $25 \mu \mathrm{L}$ of two-fold serially diluted sera with $25 \mu \mathrm{L}$ of 100 TCID $50 / \mathrm{mL}$ of the SARS-CoV-2 MAD6 isolate (kindly provided by Dr. Luis Enjuanes). The virus-serum mixture was incubated at $37^{\circ} \mathrm{C}$ with $5 \% \mathrm{CO}_{2}$. At $1 \mathrm{~h}$ post-incubation, $200 \mu \mathrm{L}$ of Vero E6 cell (provided by the Carlos III Health Institute, Madrid, Spain) suspension was added to the virus-serum mixtures, and plates were incubated at $37^{\circ} \mathrm{C}$ with $5 \% \mathrm{CO}_{2}$. Neutralization titers were determined 3 days post-infection. The titer of a sample was recorded as the reciprocal of the highest serum dilution that provided at least $100 \%$ neutralization of the reference virus, as determined by the visualization of cytopathic effect (CPE).

\subsection{Phylogenetic Analysis of SARS-CoV-2 Spike Protein by PCR Amplification and DNA Sequencing}

The $S$ protein genome from the nasal sample was sequenced using the primer walking approach with 6 primer pairs (Table 1), which were designed based on the reference genome of SARS-CoV-2 isolate Wuhan-Hu-1 (NC_045512.2). PCR was performed using the Platinum Green Hot Start PCR master mix (Invitrogen, Waltham, MA, USA) in reactions containing $15 \mu \mathrm{L}$ of master mix, $1 \mu \mathrm{L}$ of forward and reverse primers $(20 \mu \mathrm{M}), 0.5 \mu \mathrm{L}$ of RT Kapa enzyme (Kapa Biosystem, Woburn, MA, USA), $0.4 \mu \mathrm{L}$ of dNTP mix (Thermo 
Fisher Scientific, Waltham, MA, USA), $2 \mu \mathrm{L}$ of RNA template, and $5.1 \mu \mathrm{L}$ of RNAseand DNase-free water. Reactions were subjected to RT activation $\left(48^{\circ} \mathrm{C}, 15 \mathrm{~min}\right)$, initial denaturalization $\left(98^{\circ} \mathrm{C}, 30 \mathrm{~s}\right)$ and 45 cycles of denaturation at $98^{\circ} \mathrm{C}$ for $10 \mathrm{~s}$, annealing at $57^{\circ} \mathrm{C}$ for $30 \mathrm{~s}$, extension at $72{ }^{\circ} \mathrm{C}$ for $30 \mathrm{~s}$, and final extension at $72{ }^{\circ} \mathrm{C}$ for $7 \mathrm{~min}$ in a T3000 thermocycler (Biometra, Göttingen, Germany).

Table 1. Polymerase Chain Reaction (PCR) primers used for spike genome amplification based on the reference genome of SARS-CoV-2 isolate Wuhan-Hu-1 (NC_045512.2).

\begin{tabular}{cccc}
\hline Primer Pairs & Forward Primer & Reverse Primer & Product Size \\
\hline Spike-1 & TGCGTCATCATCTGAAGCAT & CGAAAAACCCTGAGGGAGAT & 973 \\
\hline Spike-2 & GGACCTTGAAGGAAAACAGG & CCTGGAGCGATTTGTCTGA & 708 \\
\hline Spike-3 & CCGCATCATTTTCCACTTTT & CGCATATACCTGCACCAATG & 903 \\
\hline Spike-4 & GCACAGAAGTCCCTGTTGCT & GGTTGGCAATCAATTTTTGG & 957 \\
\hline Spike-5 & CTGCACTGTTAGCGGGTACA & GGCGGTCAATTTCTTTTTGA & 933 \\
\hline Spike-6 & ATGATCCTTTGCAACCTGAA & ATGATTTTGGAAGCGCTCTG & 606 \\
\hline
\end{tabular}

The amplified PCR products were analyzed using $1 \%$ agarose gel electrophoresis in $45 \mathrm{mM}$ Tris borate (pH 8.0) and $2.5 \mathrm{mM}$ EDTA (0.53 TBE) containing $0.5 \mathrm{mg} / \mathrm{mL}$ ethidium bromide; DNA products were visualized by transillumination with a long-wave UV lightbox. PCR products were purified using a PCR purification kit (Qiagen, Germantown, PA, USA), and $>600 \mathrm{bp}$ (excluding primers) were sequenced using the Sanger method on an ABI Prism 3730 (Applied Biosystems, Foster City, CA, USA). The sequencing primers were the same as those used for amplification. $\mathrm{S}$ sequence was edited and assembled into the $S$ genome using MEGA 6 software [19]. The sequence was aligned with published S sequences from global initiative on sharing all influenza data (GISAID) using MUSCLE. Mutations were determined using the CoVsurver mutations app available on the GISAID website (https: / / www.gisaid.org/) (accessed on 1 July 2021). We gratefully acknowledge the various laboratories and contributors of GISAID for providing these SARS-CoV-2 sequences.

\section{Results}

The dog, a 14-year-old giant poodle male, tested positive in both nasal and rectal swabs for SARS-CoV-2 RNA detection by RT-qPCR on 24 March 2021, 7 days after its owners received a positive test result for COVID-19. The viral loads, based on PCR Ct values, were high (Table 2). The animal was asymptomatic according to the veterinary inspection, which included temperature measuring and overall clinical evaluation. Live virus isolation was possible from both the nasal and rectal swabs, with CPE noted in all passages, in which virus recovery was confirmed by using PCR. Two days after the first sampling (26 March 2021), the animal was resampled, once again showing positive results for both the nasal and rectal swabs. The swab samples showed negative results 23 days after the initial sampling (13 April 2021). Sera samples were also taken in every sampling and evaluated by VNT. While sera from first and second samplings tested negative for VNT, the serum from third sampling was positive, with a titer of $1 / 256$.

SARS-CoV-2 $\mathrm{S}$ genome sequencing was successful from the first nasal swab (GenBank reference number: MZ299152). The sequence was identified as B.1.1.7 VOC by alignment in MEGA software using the MUSCLE algorithm. According to the CoVsurver mutations app, the sequence presented the nine nucleotide changes that are characteristic of this variant, as follows: two deletions (H69del, V70del) and seven mutations (N501Y, A570D, D614G, P681H, T716I, S982A, D1118H). In addition to the distinctive B.1.1.7 mutations, the $\mathrm{S}$ sequence also showed one deletion (Y144del) and two mutations (D138H and E619K). 
Table 2. Longitudinal SARS-CoV-2 test results for a pet dog from Madrid (Spain) that was confirmed for infection with the B.1.1.7 variant of concern (VOC).

\begin{tabular}{|c|c|c|c|c|}
\hline $\begin{array}{c}\text { Animal ID, } \\
\text { Date of Sample }\end{array}$ & \multicolumn{2}{|c|}{ RT-qPCR Ct Values for Swab Testing } & $\begin{array}{l}\text { Viral Neutralization } \\
\text { Endpoint Titer }\end{array}$ & Viral Isolation \\
\hline \multirow{2}{*}{$\begin{array}{c}+\mathrm{D}-7 \\
24.03 .2021\end{array}$} & Nasal swab & Rectal swab & \multirow{2}{*}{ Negative } & \multirow{2}{*}{ Yes } \\
\hline & 20.05 & 26.34 & & \\
\hline \multirow{2}{*}{$\begin{array}{c}+\mathrm{D}-7 \\
26.03 .2021\end{array}$} & Nasal swab & Rectal swab & \multirow{2}{*}{ Negative } & \multirow{2}{*}{ NP } \\
\hline & 20.21 & 33.55 & & \\
\hline \multirow{2}{*}{$\begin{array}{c}+\mathrm{D}-7, \\
13.04 .2021\end{array}$} & Nasal swab & Rectal swab & \multirow{2}{*}{$1 / 256$} & \multirow{2}{*}{ NA } \\
\hline & ND & ND & & \\
\hline
\end{tabular}

\section{Discussion}

This is, to our knowledge, the first report of infection in a dog by the B.1.1.7 variant of SARS-CoV-2 in Spain, a country that currently presents a high prevalence of this variant [20]. The transmission of this variant from humans to their pets has also been described in the UK and the United States (US) [21,22], this being the third report documenting this event. Despite the low rate of SARS-CoV-2 infection in pets under natural conditions, VOCs can easily spread to animals who are exposed to contaminated environments. Herein, sequencing analysis was not performed from the owners' samples, but they appear to be the most likely source of infection for the dog, since the animal was quarantined with them during their infection period. Dogs' susceptibility has been demonstrated to be very low under both experimental and natural conditions $[13,23,24]$. This fact is supported by the low viral loads that have been detected in infected animals, together with the nonappearance of symptoms. However, the infection by the B.1.1.7 variant has been related to symptomatology, such as sneezing [22], or even cardiomyopathy [21]. In our study, a high viral load was detected, despite the dog not showing any clinical signs. Moreover, virus isolation was possible from both the nasal and rectal swabs. These facts may suggest that the animal was shedding infectious virus. Therefore, the dog may have been a source of infection for other pets, or even humans. Taking into account that restriction and quarantine measures in infected animals are not clearly established yet, animals infected by VOCs such as B.1.1.7 may be a risk for public health. As these variants are broadly distributed in human populations, and their transmission capacity seems to be higher than in the original virus, active surveillance should be conducted in animals, in order to prevent anthropozoonoses, and especially reverse zoonoses, which is a phenomenon that has already been demonstrated to occur with SARS-CoV-2 in the case of minks $[25,26]$. It is known that coronaviruses commonly tend to display a rapid evolution when they jump to different species [27]. In this sense, a recent study has analyzed the $S$ genes and proteins of existing SARS-CoV-2 strains that were collected from animals, to find a possible direct progenitor of variant B.1.1.7. In this study, the authors suggested that the variant strains in humans could not have evolved into the early variant B.1.1.7, but they might have infected high-density, yet susceptible, animals (such as dogs), and adapted to these species through rapid mutation. Therefore, all these results are in line with public health recommendations and highlight the importance of isolating SARS-CoV-2-infected people from their pets [28], in order to prevent human-to-pet transmission. This is especially important in the case of infection with VOCs, whose transmission and pathogenicity characteristics in animals remain unknown. 
Author Contributions: Conceptualization, S.B.-A., J.M.S.-V. and L.D.; methodology, S.B.-A. and B.R.; software, S.B.-A.; validation, S.B.-A., J.M.S.-V. and L.D.; formal analysis, S.B.-A. and J.M.S.-V.; investigation, S.B.-A., J.M.S.-V. and L.D.; resources, J.M.S.-V. and L.D.; data curation, S.B.-A.; writingoriginal draft preparation, S.B.-A.; writing-review and editing, S.B.-A. and J.M.S.-V.; visualization, S.B.-A.; supervision, J.M.S.-V.; project administration, J.M.S.-V. and L.D.; funding acquisition, J.M.S.-V. and L.D. All authors have read and agreed to the published version of the manuscript.

Funding: This study was funded by the Carlos III Institute of Health with the project "Estudio del potencial impacto del COVID19 en mascotas y linces" (COV20/01385).

Institutional Review Board Statement: The study was conducted using protocols approved by the Complutense University of Madrid's ethics committee for animal experiments (project license 14/2020, date of acceptance: 15 December 2020).

Informed Consent Statement: Not applicable.

Data Availability Statement: The data that support the findings of this study are available from the corresponding author upon reasonable request.

Acknowledgments: We appreciate the participation of the owners and their pet in this study. We are also very grateful to Sandra Ferrer, the veterinarian who took the initial samples for her willingness to collaborate always with us. We would also like to acknowledge Rocío Sánchez and Débora López for their excellent technical assistance. We are also grateful to Luis Enjuanes from the National Biotechnology Centre (CNB) at the Higher Council for Scientific Research (CSIC) for providing us the SARS-CoV-2 virus used for VNT.

Conflicts of Interest: The authors declare no conflict of interest.

\section{References}

1. Guan, W.J.; Ni, Z.Y.; Hu, Y.; Liang, W.H.; Ou, C.Q.; He, J.X.; Liu, L.; Shan, H.; Lei, C.L.; Hui, D.S.C.; et al. Clinical Characteristics of Coronavirus Disease 2019 in China. N. Engl. J. Med. 2020, 382, 1708-1720. [CrossRef]

2. Pérez-Campos, L.M.; Hernández-Huerta, M.T.; Mayoral-Andrade, G.; Pérez-Campos, E.M.; Pérez-Campos, E. A letter to the editor on "World Health Organization declares global emergency: A review of the 2019 novel Coronavirus (COVID-19)". Int. J. Surg. 2020, 79, 163-164. [CrossRef] [PubMed]

3. Kirby, T. New variant of SARS-CoV-2 in UK causes surge of COVID-19. Lancet Respir. Med. 2021, 9, e20-e21. [CrossRef]

4. Happi, A.N.; Ugwu, C.A.; Happi, C.T. Tracking the emergence of new SARS-CoV-2 variants in South Africa. Nat. Med. 2021, 27, 372-373. [CrossRef]

5. Davies, N.G.; Abbott, S.; Barnard, R.C.; Jarvis, C.I.; Kucharski, A.J.; Munday, J.D.; Pearson, C.A.B.; Russell, T.W.; Tully, D.C.; Washburne, A.D.; et al. Estimated transmissibility and impact of SARS-CoV-2 lineage B.1.1.7 in England. Science 2021, 372, eabg3055. [CrossRef] [PubMed]

6. Challen, R.; Brooks-Pollock, E.; Read, J.M.; Dyson, L.; Tsaneva-Atanasova, K.; Danon, L. Risk of mortality in patients infected with SARS-CoV-2 variant of concern 202012/1: Matched cohort study. BMJ 2021, 372, n579. [CrossRef] [PubMed]

7. Altmann, D.M.; Boyton, R.J.; Beale, R. Immunity to SARS-CoV-2 variants of concern. Science 2021, 371, 1103-1104. [CrossRef]

8. Jia, Z.; Gong, W. Will Mutations in the Spike Protein of SARS-CoV-2 Lead to the Failure of COVID-19 Vaccines? J. Korean Med. Sci. 2021, 36, e124. [CrossRef] [PubMed]

9. Bal, A.; Destras, G.; Gaymard, A.; Stefic, K.; Marlet, J.; Eymieux, S.; Regue, H.; Semanas, Q.; d'Aubarede, C.; Billaud, G.; et al. Two-step strategy for the identification of SARS-CoV-2 variant of concern 202012/01 and other variants with spike deletion H69-V70, France, August to December 2020. Eurosurveillance 2021, 26, 2100008. [CrossRef] [PubMed]

10. Shi, J.; Wen, Z.; Zhong, G.; Yang, H.; Wang, C.; Huang, B.; Liu, R.; He, X.; Shuai, L.; Sun, Z.; et al. Susceptibility of ferrets, cats, dogs, and other domesticated animals to SARS-coronavirus 2. Science 2020, 368, 1016-1020. [CrossRef]

11. Wu, K.; Peng, G.; Wilken, M.; Geraghty, R.J.; Li, F. Mechanisms of host receptor adaptation by severe acute respiratory syndrome coronavirus. J. Biol. Chem. 2012, 287, 8904-8911. [CrossRef]

12. Zhang, J.; Zhang, Y.; Kang, J.; Chen, S.; He, Y.; Han, B.; Liu, M.; Lu, L.; Li, L.; Yi, Z.; et al. Potential transmission chains of variant B.1.1.7 and co-mutations of SARS-CoV-2. bioRxiv 2021. [CrossRef]

13. Hobbs, E.C.; Reid, T.J. Animals and SARS-CoV-2: Species susceptibility and viral transmission in experimental and natural conditions, and the potential implications for community transmission. Transbound. Emerg. Dis. 2020. [CrossRef]

14. Ruiz-Arrondo, I.; Portillo, A.; Palomar, A.M.; Santibáñez, S.; Santibáñez, P.; Cervera, C.; Oteo, J.A. Detection of SARS-CoV-2 in pets living with COVID-19 owners diagnosed during the COVID-19 lockdown in Spain: A case of an asymptomatic cat with SARS-CoV-2 in Europe. Transbound. Emerg. Dis. 2020. [CrossRef]

15. Fritz, M.; Rosolen, B.; Krafft, E.; Becquart, P.; Elguero, E.; Vratskikh, O.; Denolly, S.; Boson, B.; Vanhomwegen, J.; Gouilh, M.A.; et al. High prevalence of SARS-CoV-2 antibodies in pets from COVID-19+ households. One Health 2020, 11, 100192. [CrossRef] [PubMed] 
16. Gortázar, C.; Barroso-Arévalo, S.; Ferreras-Colino, E.; Isla, J.; de la Fuente, G.; Rivera, B.; Domínguez, L.; de la Fuente, J.; Sánchez-Vizcaíno, J. Natural SARS-CoV-2 Infection in Kept Ferrets, Spain. Emerg. Infect. Dis. J. 2021, 27, 1994. [CrossRef] [PubMed]

17. Sanjuán, R.; Domingo-Calap, P. Mechanisms of viral mutation. Cell Mol. Life Sci. 2016, 73, 4433-4448. [CrossRef] [PubMed]

18. Corman, V.M.; Landt, O.; Kaiser, M.; Molenkamp, R.; Meijer, A.; Chu, D.K.; Bleicker, T.; Brünink, S.; Schneider, J.; Schmidt, M.L.; et al. Detection of 2019 novel coronavirus (2019-nCoV) by real-time RT-PCR. Eurosurveillance 2020, 25, 2000045. [CrossRef]

19. Tamura, K. Estimation of the number of nucleotide substitutions when there are strong transition-transversion and $\mathrm{G}+\mathrm{C}$-content biases. Mol. Biol. Evol. 1992, 9, 678-687. [CrossRef]

20. System, G.I.S.a.R. CoVariants (GISAID). Available online: https:/ / covariants.org/ (accessed on 1 July 2021).

21. Ferasin, L.; Fritz, M.; Ferasin, H.; Becquart, P.; Legros, V.; Leroy, E.M. Myocarditis in naturally infected pets with the British variant of COVID-19. bioRxiv 2021. [CrossRef]

22. Hamer, S.A.; Ghai, R.R.; Zecca, I.B.; Auckland, L.D.; Roundy, C.M.; Davila, E.; Busselman, R.E.; Tang, W.; Pauvolid-Corrêa, A.; Killian, M.L.; et al. SARS-CoV-2 B.1.1.7 variant of concern detected in a pet dog and cat after exposure to a person with COVID-19, USA. Transbound. Emerg. Dis. 2021. [CrossRef]

23. Temmam, S.; Barbarino, A.; Maso, D.; Behillil, S.; Enouf, V.; Huon, C.; Jaraud, A.; Chevallier, L.; Backovic, M.; Pérot, P.; et al. Absence of SARS-CoV-2 infection in cats and dogs in close contact with a cluster of COVID-19 patients in a veterinary campus. One Health 2020, 10, 100164. [CrossRef] [PubMed]

24. Bosco-Lauth, A.M.; Hartwig, A.E.; Porter, S.M.; Gordy, P.W.; Nehring, M.; Byas, A.D.; VandeWoude, S.; Ragan, I.K.; Maison, R.M.; Bowen, R.A. Experimental infection of domestic dogs and cats with SARS-CoV-2: Pathogenesis, transmission, and response to reexposure in cats. Proc. Natl. Acad. Sci. USA 2020, 117, 26382. [CrossRef] [PubMed]

25. WHO. SARS-CoV-2 Mink-Associated Variant Strain-Denmark. Available online: https://www.who.int/csr/don/06-november2020-mink-associated-sars-cov2-denmark/en/ (accessed on 1 May 2021).

26. Oude Munnink, B.B.; Sikkema, R.S.; Nieuwenhuijse, D.F.; Molenaar, R.J.; Munger, E.; Molenkamp, R.; van der Spek, A.; Tolsma, P.; Rietveld, A.; Brouwer, M.; et al. Transmission of SARS-CoV-2 on mink farms between humans and mink and back to humans. Science 2021, 371, 172. [CrossRef] [PubMed]

27. Zhou, P.; Shi, Z.L. SARS-CoV-2 spillover events. Science 2021, 371, 120-122. [CrossRef]

28. Center for Disease Control and Prevention-CDC. Pets and Other Animals. COVID-19. Available online: https://www.cdc.gov/ coronavirus / 2019-ncov/animals / pets-other-animals.html (accessed on 1 January 2021). 